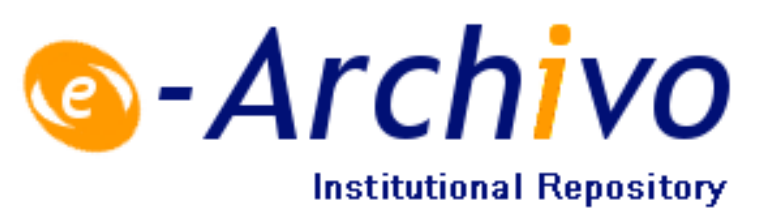

This is a postprint version of the following published document:

San Miguel, V., Álvarez, M., Filevich, O., Etchenique, R. \& del Campo, A. (2012): Multiphoton Reactive Surfaces Using Ruthenium(II) Photocleavable Cages. Langmuir, 28 (2), pp. 1217-1221.

"This document is the Accepted Manuscript version of a Published Work that appeared in final form in Langmuir, (C) 2011 American Chemical Society after peer review and technical editing by the publisher. To access the final edited and published work see http://pubs.acs.org/doi/abs/10.1021/la2033687, or see DOI: $10.1021 / 1 \mathrm{la2033687}$ ”' 


\title{
Multiphoton Reactive Surfaces Using Ruthenium(II) Photocleavable Cages
}

\author{
Verónica San Miguel, ${ }^{\dagger}$ Marta Álvarez, ${ }^{\dagger}$ Oscar Filevich, ${ }^{\ddagger}$ Roberto Etchenique, ${ }^{\ddagger}$ and Aránzazu del Campo* ${ }^{\dagger \dagger}$
}

Photoreactive surfaces derived from a new photocleavable surface modification agent and with photosensitivity in the $\mathrm{Vis}$ and IR region are described. A ruthenium(II) caged aminosilane, $\left[\mathrm{Ru}(\mathrm{bpy})_{2}\left(\mathrm{PMe}_{3}\right)\right.$ (APTS)]-( $\left(\mathrm{PF}_{6}\right)_{2}$, was synthesized and attached to silica surfaces. Light irradiation removed the cage and generated surface patterns with reactive amine groups. The photosensitivity of this compound under single $(460 \mathrm{~nm})$ and two-photon (900) excitation is demonstrated. Functional patterns with site-selective attachment of other molecular species are described.

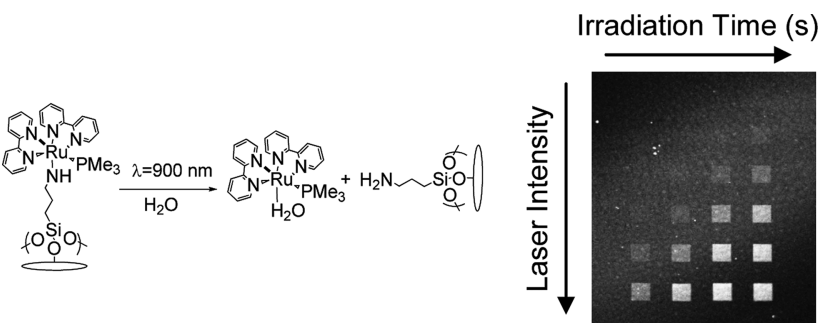

\section{INTRODUCTION}

Photoremovable groups ("cages") have been used to generate surfaces with phototriggerable chemical states. ${ }^{1}$ The caged surface contains chemical functionalities in a dormant state. Light irradiation removes the cage and activates reactivity. ${ }^{2}$ The intrinsic spatial resolution of light-induced processes allows siteselective cage removal and, therefore, the generation of caged and uncaged regions on a substrate (chemical lithography). In fact, caged surfaces have been used for the generation of microarrays of peptides, ${ }^{1 \mathrm{c}, 3}$ oligonucleotides, ${ }^{4}$ and peptoids; ${ }^{5}$ metallic nanoparticles; ${ }^{6}$ polymer colloids; ${ }^{1 \mathrm{~b}, 7}$ fluorescent dyes; $^{7,8}$ biotinylated proteins; ${ }^{1 f, 9}$ His-tagged proteins; ${ }^{10}$ or cells. $^{11}$

In most cases $o$-nitrobenzyl based cages have been used as photoremovable caging groups. More recently 2-nitrobenzyl, 7nitroindoline, coumarin-4-ylmethyl, $p$-hydroxyphenacyl, or benzoin caged surfaces were also reported. ${ }^{12}$ All of them show their optimum photoactivity in the UV spectral range, but uncaging fails or it becomes inefficient in the visible range. This fact constitutes an important limitation of caged surfaces in applications involving biological species. More recently new cages based on metal-ligand heterolytic photocleavage have been reported. ${ }^{13}$ Ruthenium bipyridyl complexes have been used to cage amine groups in different molecules. ${ }^{13}$ Uncaging has been demonstrated using light at $450 \mathrm{~nm}$ with fast kinetics (in the ns range) and good yields $(\phi=0.13 \text { at } \mathrm{pH} 7)^{14}$ Ruthenium bipyridyl complexes also show decent two-photon absorption cross sections ( $0.14 \mathrm{GM})$ that allowed efficient photocleavage in solution using IR light $(800 \mathrm{~nm}) .{ }^{14}$ These compounds can be prepared by complexation reactions in mild conditions and their photochemical and photophysical properties can be tuned by changing the chemical nature of the ligands. In this manuscript we synthesize and analyze the surface attachment and photocleavage of $\mathrm{Ru}$ complexes coordinated to an amine terminated surface coupling agent, $\left.\mathrm{Ru}(\mathrm{bpy})_{2}\left(\mathrm{PMe}_{3}\right)(\mathrm{APTS})\right]\left(\mathrm{PF}_{6}\right)_{2}$ (see Scheme 1) in the Vis and $\mathrm{IR}$ region. Our results show that the $\mathrm{Ru}$ complexes are promising systems to be used as caging groups in surface applications.

\section{EXPERIMENTAL SECTION}

Materials and Methods. All reagents were commercially available and used as received. DOWEX $22 \mathrm{Cl}$ anion exchange resin, 3aminopropyltriethoxysilane 99\%, and potassium hexafluorophosphate 98\% were purchased from Sigma-Aldrich Chemie GmbH (Steinheim, Germany). Quartz substrates (Suprasil) with a thickness of $1 \mathrm{~mm}$ were purchased from Heraeus Quarzglas (Hanau, Germany). Alexa Fluor 488 carboxylic acid succinimidyl ester was purchased from Invitrogen (Eugene, U.S.A.).

Solution ${ }^{1} \mathrm{H}$ NMR spectra were recorded on a Bruker Spectrospin $300 \mathrm{MHz}$. UV/Vis spectra were recorded using JAZ-COMBO spectrometer (Ocean Optics Inc., Dunedin, U.S.A.) to follow the reactions in solution and a Varian Cary $4000 \mathrm{UV} /$ Vis spectrometer (Varian Inc., Palo Alto, U.S.A.) when measuring surface modified quartz substrates.

Synthesis of Ruthenium Complexes. All solutions were degassed with $\mathrm{N}_{2}$ prior to heating to prevent oxidation of the ruthenium aquo complexes.

$\left[R u(b p y)_{2}\left(\mathrm{PMe}_{3}\right) C l\right] P F_{6}$ (1). 1 was synthesized as previously reported. ${ }^{14}$

$\left[R u(b p y)_{2}\left(\mathrm{PMe}_{3}\right)\left(\mathrm{H}_{2} \mathrm{O}\right)\right]\left(\mathrm{PF}_{6}\right)_{2}$ (2). A total of $50 \mathrm{mg}$ of $[\mathrm{Ru}-$ $\left.(\text { bpy })_{2}\left(\mathrm{PMe}_{3}\right) \mathrm{Cl}\right]\left(\mathrm{PF}_{6}\right)_{2}$ was dissolved in $8 \mathrm{~mL}$ of a mixture acetone/water (1:2) and $500 \mathrm{mg}$ of a chloride-containing anionic exchange resin (DOWEX $22 \mathrm{Cl}$ ) was added. The acetone was

\footnotetext{
${ }^{\dagger}$ Max-Planck-Institut für Polymerforschung. Ackermannweg 10, 55128 Mainz, Germany

*Departamento de Química Inorganica, Analítica y Química Física, INQUIMAE, Facultad de Ciencias Exactas y Naturales, Universidad de Buenos Aires, Ciudad Universitaria Pabellón 2 Piso 3, C1428EHA Buenos Aires, Argentina
}

Tel: +496131 379 516. Fax: +496131 379 271. E-mail: delcampo@mpip-mainz.mpg.de. 
Scheme 1. Synthetic Route for Obtaining $\left[\mathrm{Ru}(\mathrm{bpy})_{2}\left(\mathrm{PMe}_{3}\right)(\mathrm{APTS})\right]\left(\mathrm{PF}_{6}\right)_{2}$

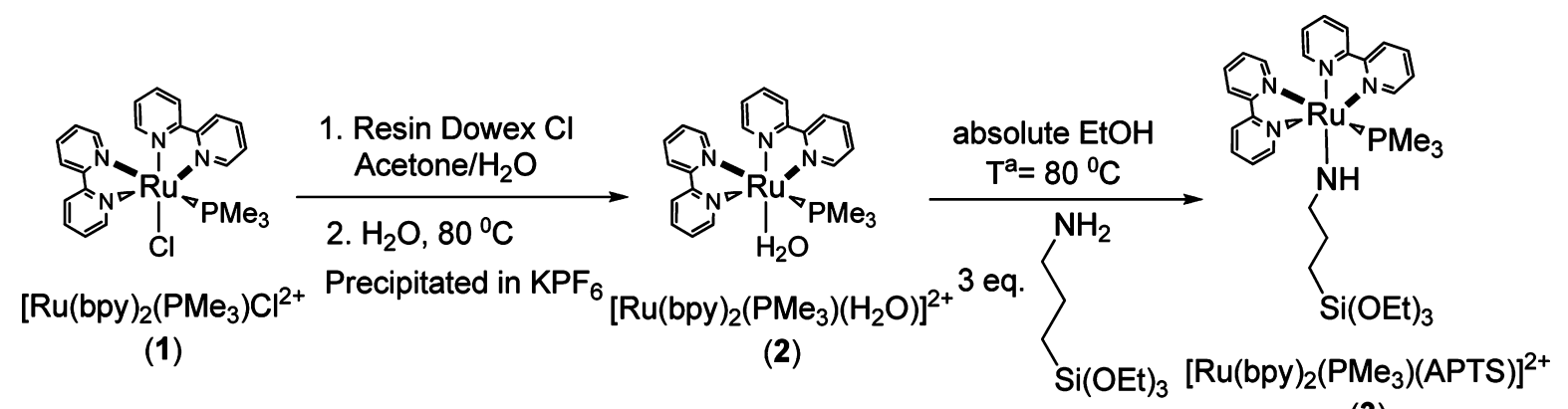

(3)

evaporated and the suspension was stirred overnight. The resulting aqueous $\left[\mathrm{Ru}(\text { bpy })_{2}\left(\mathrm{PMe}_{3}\right) \mathrm{Cl}\right] \mathrm{Cl}$ solution was filtered to remove the resin and heated at $80{ }^{\circ} \mathrm{C}$ for $1 \mathrm{~h}$ until $\left[\mathrm{Ru}(\text { bpy })_{2}\left(\mathrm{PMe}_{3}\right)\left(\mathrm{H}_{2} \mathrm{O}\right)\right]^{2+}$ was obtained. The progress of the reaction was followed in situ by UV-Vis spectroscopy. A red-shift of $\lambda_{\max }$ from $\sim 446$ to $\sim 460 \mathrm{~nm}$ at basic $\mathrm{pH}$ evidenced the appearance of the hidroxo complex $\left[\mathrm{Ru}(\mathrm{bpy})_{2}\left(\mathrm{PMe}_{3}\right)\right.$ $(\mathrm{OH})]^{+}$. The solution was cooled to $0{ }^{\circ} \mathrm{C}$, and the final compound was precipitated by addition of a saturated solution of $\mathrm{KPF}_{6}(0.5 \mathrm{M})$ to the mixture. The orange-brown solid ( $40 \mathrm{mg}, 83 \%)$ was filtered and dried in the desiccator overnight. ${ }^{1} \mathrm{H}$ NMR $\left(300 \mathrm{MHz}\right.$, acetone- $\left.\mathrm{D}^{6}\right): \delta 1.12$ $\left(\mathrm{d}, J=8.9 \mathrm{~Hz}, 9 \mathrm{H}, 3 \mathrm{xCH}_{3}\right), 7.31(\mathrm{~m}, 2 \mathrm{H}, \mathrm{Ar}-\mathrm{H}), 7.45(\mathrm{~m}, 1 \mathrm{H}, \mathrm{Ar}-$ $\mathrm{H}), 7.62(\mathrm{~m}, 1 \mathrm{H}, \mathrm{Ar}-\mathrm{H}), 7.86(\mathrm{~m}, 1 \mathrm{H}, \mathrm{Ar}-\mathrm{H}), 7.89-7.97(\mathrm{~m}, 2 \mathrm{H}$, $\mathrm{Ar}-\mathrm{H}), 8.00-8.11(\mathrm{~m}, 2 \mathrm{H}, \mathrm{Ar}-\mathrm{H}), 8.24(\mathrm{~m}, 1 \mathrm{H}, \mathrm{Ar}-\mathrm{H}), 8.39(\mathrm{~m}$, $1 \mathrm{H}, \mathrm{Ar}-\mathrm{H}), 8.53-8.77$ (m, 3H, Ar-H), $9.36(\mathrm{~m}, 1 \mathrm{H}, \mathrm{Ar}-\mathrm{H}), 9.44$ $(\mathrm{m}, 1 \mathrm{H}, \mathrm{Ar}-\mathrm{H})$.

$\left[R u(b p y)_{2}\left(P M e_{3}\right)(A P T S)\right]\left(P F_{6}\right)_{2}$ (3). $\left[\mathrm{Ru}(\mathrm{bpy})_{2}\left(\mathrm{PMe}_{3}\right)\left(\mathrm{H}_{2} \mathrm{O}\right)\right]\left(\mathrm{PF}_{6}\right)_{2}$ $(60 \mathrm{mg}, 111 \mu \mathrm{mol})$ was dissolved in absolute ethanol $(6 \mathrm{~mL})$, and the suspension was filtered to remove the insoluble particles. The solution was heated to $80{ }^{\circ} \mathrm{C}$ and 3-aminopropyltriethoxysilane $(77 \mu \mathrm{L}, 330$ $\mu \mathrm{mol})$ was added. The mixture was stirred for $5 \mathrm{~h}$ until the reaction was completed (no further shift of $\lambda_{\max } \approx 460 \mathrm{~nm}$ at basic $\mathrm{pH}$ with time). The solution was concentrated and the residual orange-brown oil $(0.50 \mathrm{mg}, 92 \%)$ was dried in the vacuum line overnight at $40{ }^{\circ} \mathrm{C}$ and used without further purification. ${ }^{1} \mathrm{H}$ NMR $(300 \mathrm{MHz}$, acetone$\left.\mathrm{D}^{6}\right): \delta 0.78-0.92\left(\mathrm{~m}, 2 \mathrm{H}, \mathrm{CH}_{2}\right), 1.05-1.19\left(\mathrm{~m}, 18 \mathrm{H}, 6 \mathrm{xCH}_{3}\right), 1.21-$ $1.42\left(\mathrm{~m}, 2 \mathrm{H}, \mathrm{CH}_{2}\right), 3.41\left(\mathrm{~m}, 4 \mathrm{H}, 2 \mathrm{xCH}_{2}\right), 3.48-3.71\left(\mathrm{~m}, 6 \mathrm{H}, 3 \mathrm{xCH}_{2}\right)$, $7.32(\mathrm{~m}, 2 \mathrm{H}, \mathrm{Ar}-\mathrm{H}), 7.41(\mathrm{~m}, 1 \mathrm{H}, \mathrm{Ar}-\mathrm{H}), 7.57(\mathrm{~m}, 1 \mathrm{H}, \mathrm{Ar}-\mathrm{H})$, 7.73-8.10 (m, 5H, Ar-H), 8.12-8.36 (m, 2H, Ar-H), 8.50-8.74 (m, $3 \mathrm{H}, \mathrm{Ar}-\mathrm{H}), 9.36(\mathrm{~m}, 1 \mathrm{H}, \mathrm{Ar}-\mathrm{H}), 9.86(\mathrm{~m}, 1 \mathrm{H}, \mathrm{Ar}-\mathrm{H})$.

Substrate Cleaning. Quartz slides of $1 \times 2.5 \mathrm{~cm}^{2}$ were cut and cleaned by soaking them in Piranha solution $\left(\mathrm{H}_{2} \mathrm{SO}_{4}\right.$ (conc)/ $\left.\mathrm{H}_{2} \mathrm{O}_{2}(30 \%), 5 / 1\right)$ overnight and subsequent rinsing with Milli-Qwater and drying in vacuum at $90{ }^{\circ} \mathrm{C}$ for one hour.

Surface Modification with $\left[\mathrm{Ru}(\mathrm{bpy})_{2}\left(\mathrm{PMe}_{3}\right)(\mathrm{APTS})\right]^{2+}$. A $1 \%$ $\mathrm{w} / \mathrm{v}$ solution of the ruthenium(II) complex $\left[\mathrm{Ru}(\mathrm{bpy})_{2}\left(\mathrm{PMe}_{3}\right)\right.$ (APTS) $]^{2+}$ in acetone with $20 \mu \mathrm{L}$ of $1 \mathrm{~N} \mathrm{NaOH} \mathrm{(aq)} \mathrm{was} \mathrm{stirred}$ for $30 \mathrm{~min}$. The solution was filtrated through a $0.2 \mu \mathrm{m}$ pore-size PTFE filter in the reaction vessel, and clean quartz substrates were immersed in it. After $24 \mathrm{~h}$, the substrates were rinsed with acetone and Milli-Q water to remove physisorbed molecules, baked for $1 \mathrm{~h}$ at $90{ }^{\circ} \mathrm{C}$ in a vacuum oven, and stored in the dark. Before further application, all substrates were sonicated in ethanol/water $(1: 1)$ for $3 \mathrm{~min}$, washed with ultrapure water, and dried with a $\mathrm{N}_{2}$ stream.

Characterization of Surface Layers. The surface modification process was followed by recording UV/Vis spectra on quartz substrates at different reaction times. The surface density of the chromophore, $\Gamma$ (molecules $\mathrm{cm}^{-2}$ ), was estimated from the UV absorbance using $\Gamma={ }^{1} /{ }_{2}\left[A_{\lambda} \varepsilon_{\lambda}^{-1} N_{\mathrm{A}}\right]$, where $A_{\lambda}$ is the absorbance of the surface layer at a given wavelength, $\varepsilon_{\lambda}$ is the molar extinction coefficient of the chromophore in solution at $\lambda_{\max }\left(\varepsilon_{460} \approx 4000 \mathrm{M}^{-1}\right.$ $\mathrm{cm}^{-1}$; extinction coefficient value taken from $\left[\mathrm{Ru}(\mathrm{bpy})_{2}\left(\mathrm{PMe}_{3}\right)\right.$ (Glu)]), ${ }^{14}$ and $N_{\mathrm{A}}$ is Avogadro's number. ${ }^{15}$ The factor $1 / 2$ refers to the fact that the quartz slides are modified on both sides. Note that this calculation assumes that the molar extinction coefficient of the chromophore in solution and at the surface is the same. This is true only if anchored chromophore-chromophore or chromophoresurface interactions are disregarded. ${ }^{15}$

Single-Photon Photocleavage at the Surface. Irradiation of $\left[\mathrm{Ru}(\mathrm{bpy})_{2}\left(\mathrm{PMe}_{3}\right)(\mathrm{APTS})\right]^{2+}$ modified substrates was carried out in presence of water and under ambient laboratory conditions using a Polychrome V system (TILL Photonics GmbH, Gräfelting, Germany). The wavelength and irradiance used were $460 \mathrm{~nm}$ and $1.59 \mathrm{~mW} \mathrm{~cm}$, respectively. After irradiation, substrates were sonicated in ethanol/ water (1:1), rinsed with Milli-Q water, and dried with a $\mathrm{N}_{2}$ stream before characterization by UV-Vis spectroscopy.

For laterally structured deprotection at $460 \mathrm{~nm}$, the substrates were irradiated through quartz masks containing micrometric chrome squares $(10 \mu \mathrm{m}$, provided by ML\&C, Jena, Germany).

Calculation of the Photolytic Efficiency (Conversion and $\varepsilon_{\lambda} \phi$ Product). The conversion of the photolytic reaction was calculated from the absorbance decay at $\lambda_{\max }$ measured by UV spectroscopy on modified quartz substrates after exposure with increasing dose and washing. The ratio of the absorbance at $\lambda_{\max }$ after irradiation to the amount of initial absorbance multiplied by 100 gave the percent of chromophore remaining after exposure for a given time. From this, the conversion (\%) upon exposure was found by subtraction for the different doses. The product $\varepsilon_{\lambda} \phi$ for exposure wavelength was calculated by fitting the conversion curve to the photokinetic equation

$$
\frac{\mathrm{d} x}{\mathrm{~d} t}=-I_{0} \ln (10) \varepsilon_{\lambda} \varphi x
$$

which was specially developed for photolysis experiments at surfaces. ${ }^{12,16}$ In this equation $x$ represents the relative surface coverage of the photoreactive group and $I_{0}$ is the illumination intensity in einstein per units of time and area.

Fluorescent Labeling. Patterned substrates were stained with Alexa Fluor 488 carboxylic acid succinimidyl ester. A solution (150 $\mu \mathrm{L})$ of the dye in DMSO $(10 \mu \mathrm{g} / \mathrm{mL})$ was deposited on one side of the dried substrate and incubated at RT for two hours in the dark. After washing with DMSO and ultrapure water, the fluorescence was analyzed with a confocal laser scanning microscope (Carl Zeiss GmbH, Jena, Germany) consisting of the module LSM 510 and an inverted microscope model Axiovert 200.

Two-Photon Photocleavage at the Surface. Square patterns with different irradiation doses were written onto $\left[\mathrm{Ru}(\mathrm{bpy})_{2}\left(\mathrm{PMe}_{3}\right)\right.$ $(\mathrm{APTS})]^{2+}$ modified substrates using a titanium:sapphire laser (Ti:Sa; Mai Tai, Spectra Physics Inc., U.S.A.) coupled to the confocal microscope setup described above. This laser is tunable from $\lambda=780$ to $920 \mathrm{~nm}$ and provides $\sim 100 \mathrm{fs}$ pulses at a repetition rate of $80 \mathrm{MHz}$. The laser light was tightly focused by the microscope objective on the ruthenium complex-coated substrate to a spot with a diameter of $\sim 1$ $\mu \mathrm{m}$. As the complex has its absorption maximum around $460 \mathrm{~nm}$, the laser wavelength of $900 \mathrm{~nm}$ was selected for the two-photon patterning experiments. The maximum time-averaged laser power in the object plane at this wavelength was about $75 \mathrm{~mW}$. Using the galvanometric mirrors of the LSM 510, the focal spot was continuously rasterscanned (512 lines) on the substrate surface, creating squared illuminated patterns with a typical size of $45 \mu \mathrm{m} \times 45 \mu \mathrm{m}$. Both, 
the total exposure time and the applied laser power were varied in order to study the effect of these parameters on the deprotection.

Quantification of Fluorescence Data and Contrast. The average fluorescence intensities of irradiated and nonirradiated areas after labeling $\left(I_{\mathrm{F}, \mathrm{I}}\right.$ and $\left.\mathrm{I}_{\mathrm{F}, \mathrm{NI}}\right)$ were calculated using the software ImageJ1.41o by Wayne Rasband from National Institute of Health, U.S.A.

\section{RESULTS AND DISCUSSION}

The $\left[\mathrm{Ru}(\mathrm{bpy})_{2}\left(\mathrm{PMe}_{3}\right) \mathrm{Cl}\right] \mathrm{PF}_{6}$ complex was successfully used to cage the amine group of aminopropyl(triethoxysilane) and to render a new photocleavable surface modification agent (compound 3, Scheme 1). Quartz substrates were modified with 3 by silanization and the reaction on the surface was followed by UV-Vis spectroscopy of the functionalized substrates (Figure $1 \mathrm{~b}$; spectrum of the complex 3 in solution
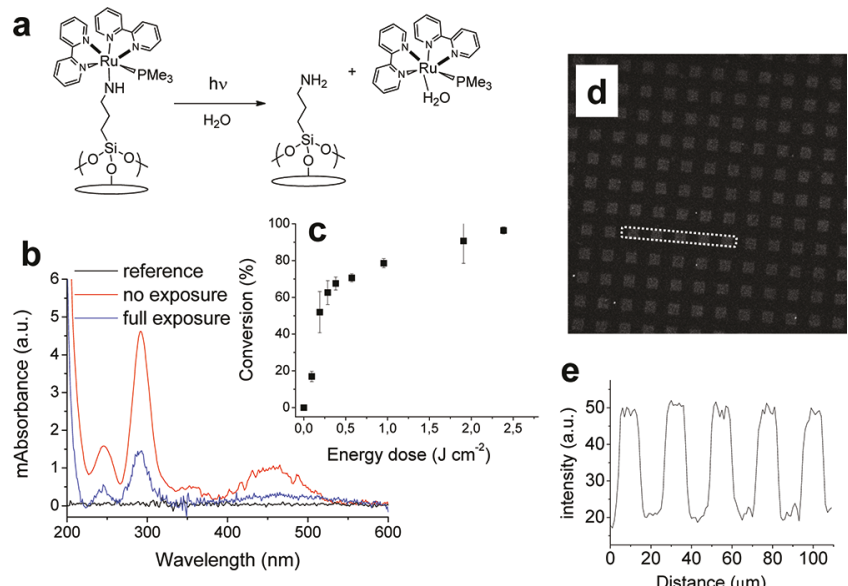

Figure 1. (a) Deprotection scheme of the $\left[\mathrm{Ru}(\mathrm{bpy})_{2}\left(\mathrm{PMe}_{3}\right)\right.$ (APTS) $]^{2+}$ modified surface. (b) UV-Vis spectrum of quartz substrates modified with $\left[\mathrm{Ru}(\mathrm{bpy})_{2}\left(\mathrm{PMe}_{3}\right)(\mathrm{APTS})\right]^{2+}$ before and after full exposure at $460 \mathrm{~nm}$. (c) Conversion (\%) plot versus energy dose upon irradiation at $460 \mathrm{~nm}$ in presence of water. (d) Fluorescence pattern of Alexa Fluor 488 of modified substrates showing $20 \mu \mathrm{m}$ bright (exposed) squares. (e) Fluorescence intensity profile from marked squares in d).

is shown in the Supporting Information). The presence of the chromophore at the surface was detected by the appearance of the characteristic absorbance bands of $\left[\mathrm{Ru}(\text { bpy })_{2}\left(\mathrm{PMe}_{3}\right)\right.$ $\left.\mathrm{NH}_{2} \mathrm{R}\right]^{2+}$ at 290 and $460 \mathrm{~nm}$. The band at $290 \mathrm{~nm}$ is assigned to $\pi^{*} \leftarrow \pi$ transitions localized at the bipyridines. ${ }^{17}$ The maximum at $460 \mathrm{~nm}$ corresponds to the metal-to-ligand charge transfer (MLCT) band, characteristic of this family of $\mathrm{Ru}$ polypyridines. ${ }^{13}$ The estimated surface density of the chromophore under optimized reaction conditions was $7.0 \times$ $10^{13}$ molecules $\mathrm{cm}^{-2}$.

Alternatively, caged ruthenium(II) complex surfaces were prepared by direct reaction of $\left[\mathrm{Ru}(\mathrm{bpy})_{2}\left(\mathrm{PMe}_{3}\right) \mathrm{Cl}\right] \mathrm{PF}_{6}$ or $\left[\mathrm{Ru}(\mathrm{bpy})_{2}\left(\mathrm{PMe}_{3}\right)\left(\mathrm{H}_{2} \mathrm{O}\right)\right]\left(\mathrm{PF}_{6}\right)_{2}$ with a surface modified with 3-aminopropyltriethoxysilane (see details in the Supporting Information). Both routes rendered surfaces with much lower density of the chromophore. For this reason, the previous method was preferred.

The obtained surfaces were light-irradiated in order to test the photocleavable properties of the surface attached $[\mathrm{Ru}-$ $\left.(\mathrm{bpy})_{2}\left(\mathrm{PMe}_{3}\right)(\mathrm{APTS})\right]^{2+}$. The photocleavage reaction is represented in Figure 1a and yields a free amine at the surface and release of $\left[\mathrm{Ru}(\mathrm{bpy})_{2}\left(\mathrm{PMe}_{3}\right)\left(\mathrm{H}_{2} \mathrm{O}\right)\right]^{2+}$. The photolysis mechanism involves irradiation on the MLCT band of the complex. Absorption at this band populates a triplet state that is thermally activated to a dissociative $\mathrm{d}$ - $\mathrm{d}$ state, which leads to the heterolytic cleavage yielding the photoproducts: the aquocomplex and the free ligand. ${ }^{18}$ It is interesting to point out that the quantum efficiency of photocleavage depends on the basicity of the ligands. Phosphine ligands, however, are usually not photocleavable; ${ }^{19}$ therefore, the complex will only photoremove the amine ligand.

The progress of the reaction at the surface was followed by the decay in the UV absorbance of the substrates upon light exposure at $\lambda=460 \mathrm{~nm}$ in presence of water and subsequent washing of the photocleaved byproduct. Figure $1 \mathrm{~b}$ shows the spectral evolution. The absorbance decreases upon increasing exposure up to $20 \mathrm{~min}$. After full exposure a residual absorbance was still visible. Taking into account that the chemical yield of the photolysis of the $\mathrm{Ru}$ cage is almost quantitative, ${ }^{14}$ the residual absorbance is attributed to photolytic byproducts that remained adsorbed onto the surface layer and could not be washed out.

The conversion of the photolytic reaction upon irradiation was estimated from the UV-Vis spectra and is represented in Figure 1c (see the Experimental Section for details). From this curve, the photosensitivity of the chromophore (the product of the absorption coefficient $\left(\varepsilon_{\lambda}\right)$ and the quantum yield $(\phi)$ at the given wavelength) can be estimated using a previously reported photokinetic equation model for the special case of photolysis at surfaces. ${ }^{12,16}$ A value of $\varepsilon_{\lambda} \phi=631 \mathrm{M}^{-1} \mathrm{~cm}^{-1}$ was obtained. Taking $\varepsilon_{460} \approx 4000 \mathrm{M}^{-1} \mathrm{~cm}^{-1}$ (reported value from $\left[\mathrm{Ru}(\mathrm{bpy})_{2}\left(\mathrm{PMe}_{3}\right)(\mathrm{Glu})\right]$ in solution $\left.{ }^{14}\right)$, a quantum yield of 0.16 for the photolysis of the $\mathrm{Ru}$ complex at the surface could be estimated. This value agrees with the reported value for $\left[\mathrm{Ru}(\text { bpy })_{2}\left(\mathrm{PMe}_{3}\right)(\mathrm{Glu})\right]$ from solution experiments, $\phi=0.13$ at $\mathrm{pH} 7^{14}$ and indicates that the uncaging reaction at the surface and in solution proceeds with similar mechanism and characteristics.

In order to prove that the photolytic reaction renders free and functional amine groups at the surface, $\left[\mathrm{Ru}(\mathrm{bpy})_{2}\left(\mathrm{PMe}_{3}\right)\right.$ (APTS $)]^{2+}$ modified surfaces were irradiated through a mask to generate a pattern of uncaged/caged areas, and reacted with a fluorescent dye that specifically attaches to free amine groups. A fluorescent pattern of bright (uncaged) and dark (caged) areas reflecting the shape of the mask was visualized at the fluorescent microscope (Figure 1, panels $\mathrm{d}$ and e). This result confirmed the generation of fully functional amine groups after light exposure.

We then tested the photoreactivity of $\left[\mathrm{Ru}(\mathrm{bpy})_{2}\left(\mathrm{PMe}_{3}\right)\right.$ $(\mathrm{APTS})]^{2+}$ modified surfaces in the IR region exploiting multiphoton excitation. It is important to note that two-photon uncaging of ruthenium bipyridyl complexes in solution has been recently demonstrated and reported. ${ }^{14,20}$ In the present work, two-photon uncaging of the modified surface layer was tested by scanning the surface at $900 \mathrm{~nm}$ in the presence of water with a high intensity Ti:Sa laser. In order to identify the energy threshold for the cleavage, several squares of $45 \mu \mathrm{m} \times$ $45 \mu \mathrm{m}$ were written by raster scanning, forming an array of squares exposed at different average intensities $(I)$ (from $\sim 2$ to $75 \mathrm{~mW}$ ) and irradiation times $(t)$ (between 2 and $62 \mathrm{~s}$ ). In this way, each square corresponds to a two-photon dose defined as $D_{2 p}=I^{2} t^{21}$ Note that the relative change in the laser intensity can be determined with much higher accuracy than the absolute light intensity at the surface; for this reason, only relative units (\%) are stated and used for further analysis. Immediately after 
irradiation, the sample was incubated with a solution of AlexaFluor 488 carboxylic acid succinimidyl ester in order to label the free amino groups on the surface. The surface density of the dye (as revealed by the fluorescence intensity) is a measure of the extent of the uncaging reaction for a given $D_{2 p}$.

Figure 2 shows the results. A clear transition from a low dose zone where no fluorescent pattern was detected (top left), to a

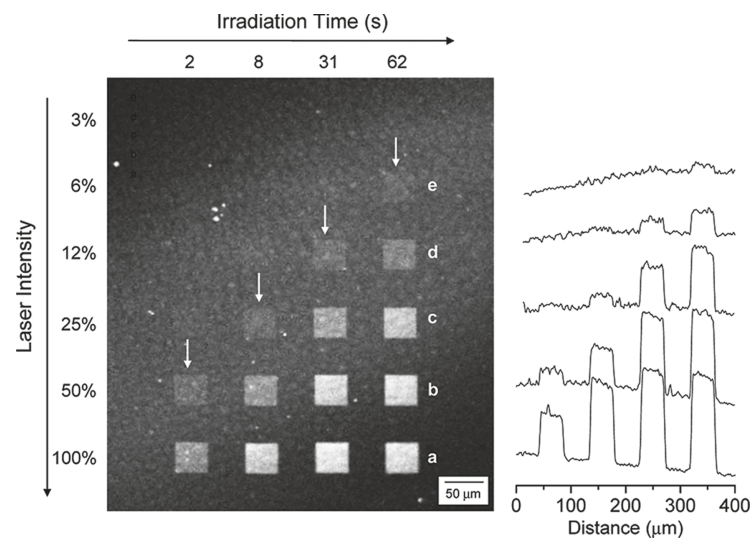

Figure 2. Fluorescence micrograph of an AlexaFluor 488 decorated ruthenium(II) complex silane modified surface after femtosecond-laser patterning exposition to $900 \mathrm{~nm}$. Each square corresponds to a specific laser intensity and irradiation time as indicated in the graph. Fluorescence profile for the squares irradiated at the same laser intensity and different times (inset).

high dose zone with strong fluorescent squares (bottom right) could be observed. The contrast between the squares and the background increases until a certain saturation value. These results demonstrate the possibility of uncaging surface bound $\mathrm{Ru}$ cages via two-photon processes. In addition, the uncaging process can be site-selective and the uncaging ratio is dose- dependent and can be controlled by the laser intensity or by the exposure time.

In order to estimate the degree of uncaging at a certain exposure dose, the difference in fluorescence signal between the illuminated areas and the surrounding regions (i.e., the contrast) was extracted for the different squares and represented as a function of the exposure dose. ${ }^{21}$ The contrast was calculated as $C=100\left[\left(I_{\mathrm{F}, \mathrm{I}}-I_{\mathrm{F}, \mathrm{NI}}\right) / I_{\mathrm{F}, \mathrm{I}}\right]$, where $I_{\mathrm{F}, \mathrm{I}}$ and $I_{\mathrm{F}, \mathrm{NI}}$ are the average fluorescence intensities of the irradiated and nonirradiated areas respectively. Taking into account that the rate for a general $n$-photon induced process to occur depends on the $n$-th power of the light intensity, $I^{n}$, ${ }^{22}$ the degree of uncaging in a $n$-photon process, is expected to correlate with the $n$-photon dose, $D_{n}=I^{n} t$. A plot of $C$ for as a function of $D_{n}$ for the different irradiation times can therefore discriminate between different multiphoton processes. Figure 3a shows $C$ plotted versus $I^{2} t(n=2)$, which presents a collapse to a single curve, confirming that a two-photon deprotection mechanism is consistent with our data. For comparison, $C$ was also represented versus $I t$ and $I^{3} t(n=1$ in Figure $3 \mathrm{~b}$ and $n=3$ in Figure 3c). Different curves are obtained in these cases for different irradiation doses, pointing out that single- or threephoton processes are not responsible for the contrast generation in our experiment.

The threshold dose for the two-photon photocleavage $\left(D_{2 p-t}\right)$ corresponds to the exposure dose used at the marked squares in Figure 2 (white arrows). The obtained $D_{2 \mathrm{p}-\mathrm{t}}$ values at $900 \mathrm{~nm}$ (Figure 3) are $D_{2 \mathrm{p}-\mathrm{t}}=(6 \%)^{2} \cdot 62 \mathrm{~s}=2232 \%^{2} \mathrm{~s}, D_{2 \mathrm{p}-\mathrm{t}}=(12 \%)^{2} \cdot 31$ $\mathrm{s}=4464 \%^{2} \mathrm{~s}$, and $D_{2 \mathrm{p}-\mathrm{t}}=(25 \%)^{2} \cdot 8 \mathrm{~s}=(50 \%)^{2} \cdot 2 \mathrm{~s}=5000 \%^{2} \mathrm{~s}$. The threshold dose for the different intensity and time combinations is consistently between 2200 and $5000 \%{ }^{2}$ s.

\section{CONCLUSIONS}

We have demonstrated that free amine groups can be photogenerated on a surface using a new photocleavable
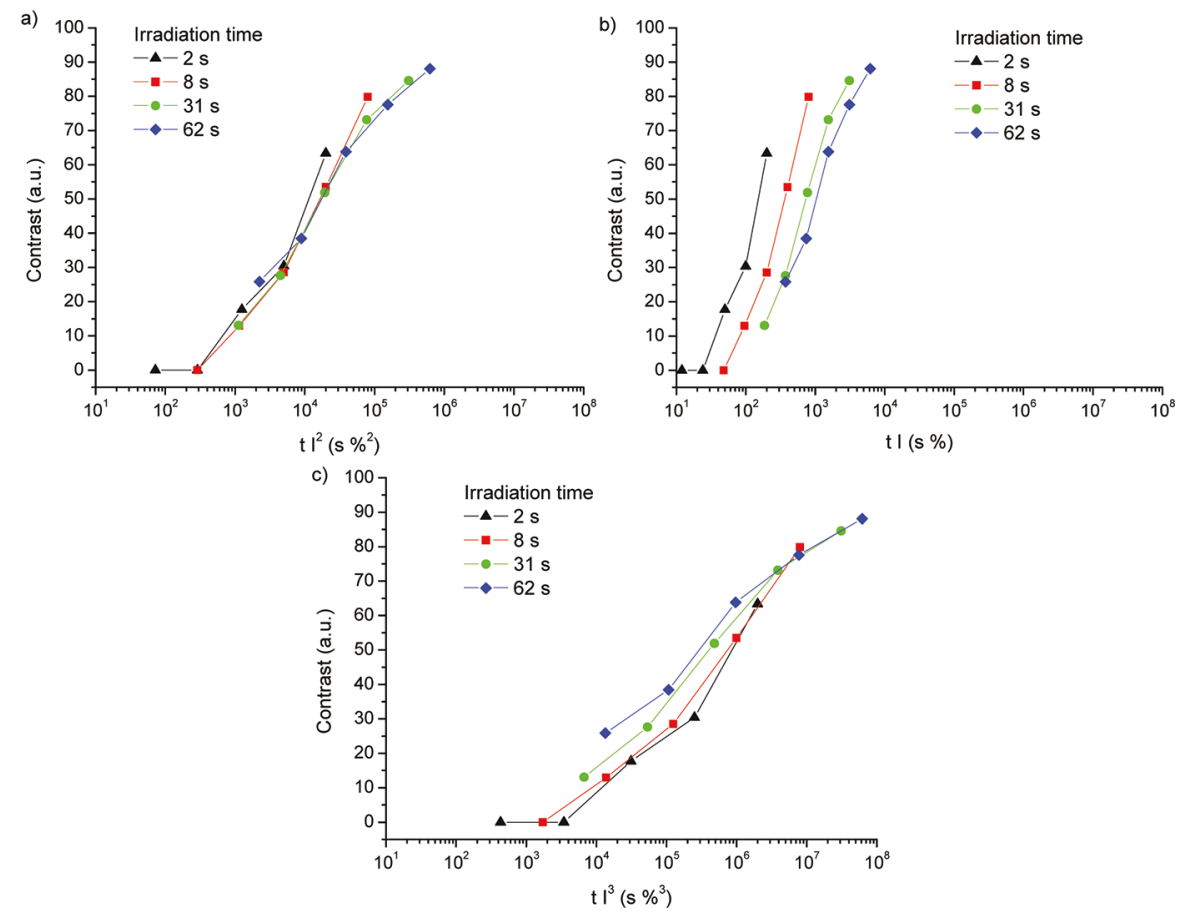

Figure 3. Contrast versus dose curves (extracted from Figure 2) upon exposure at $900 \mathrm{~nm}$ for the ruthenium(II) complex silane assuming (a) two-, (b) one-, and (c) three-photon absorption process. 
ruthenium(II) caged aminosilane and light exposure at 460 and $900 \mathrm{~nm}$ via single and two-photon excitation mechanisms. The amine groups are fully functional and can be reacted with other molecules after the photoactivation. Our results demonstrate the potential of $\mathrm{Ru}$ (II) complexes to be applied for surface patterning and functionalization in biological applications, where UV light of shorter wavelengths may damage the biological species. This principle could also be extended from the $2 \mathrm{D}$ surfaces to $3 \mathrm{D}$ bulk materials, where two-photon excitation would allow 3D micrometric resolution of the activated volume. These experiments are in progress in the group.

\section{ACKNOWLEDGMENTS}

A.d.C., O.F., and R.E. thank the DFG (444ARG113/8/1-0) for financial support. The authors thank Beatriz Garcia (INQUIMAE) for helping with the synthesis part, Andreas Best (MPIP) for the laser scanning experiments, and Juan P. Fernández-Blázquez (MPIP) for help the contrast measurements. R.E. is staff member of CONICET.

\section{REFERENCES}

(1) (a) Fodor, S. P. A; Read, J. L.; Pirrung, M. C.; Stryer, L.; Lu, A. T.; Solas, D. Science 1991, 251, 767. (b) Pirrung, M. C.; Huang, C. Y. Bioconjugate Chem. 1996, 7, 317. (c) Pirrung, M. C.; Fallon, L.; McGall, G. J. Org. Chem. 1998, 63, 241. (d) del Campo, A.; Boos, D.; Spiess, H. W.; Jonas, U. Angew. Chem.-Int. Ed. 2005, 44, 4707. (e) Alonso, J. M.; Reichel, A.; Piehler, J.; del Campo, A. Langmuir 2008, 24, 448. (f) Petersen, S.; Alonso, J. M.; Specht, A.; Duodu, P.; Goeldner, M.; Del Campo, A. Angew. Chem., Int. Ed. 2008, 47, 3192. (g) Stegmaier, P.; Alonso, J. M.; del Campo, A. Langmuir 2008, 24, 11872. (h) Stegmaier, P.; del Campo, A. ChemPhysChem 2009, 10, 357.

(2) (a) Pillai, V. N. R. Synthesis 1980, 1. (b) Bochet, C. G. J. Chem. Soc., Perkin Trans. 1 2002, 125. (c) Mayer, G.; Heckel, A. Angew. Chem.-Int. Ed. 2006, 45, 4900.

(3) Pellois, J. P.; Wang, W.; Gao, X. L. J. Comb. Chem. 2000, 2, 355. (4) (a) Pease, A. C.; Solas, D.; Sullivan, E. J.; Cronin, M. T.; Holmes, C. P.; Fodor, S. P. A Proc. Natl. Acad. Sci. U.S.A. 1994, 91, 5022. (b) McGall, G.; Labadie, J.; Brock, P.; Wallraff, G.; Nguyen, T.; Hinsberg, W. Proc. Natl. Acad. Sci. U.S.A. 1996, 93, 13555. (c) McGall, G. H.; Barone, A. D.; Diggelmann, M.; Fodor, S. P. A; Gentalen, E.; Ngo, N. J. Am. Chem. Soc. 1997, 119, 5081. (d) Gao, X. L.; Yu, P. L.; LeProust, E.; Sonigo, L.; Pellois, J. P.; Zhang, H. J. Am. Chem. Soc. 1998, 120, 12698. (e) Singh-Gasson, S.; Green, R. D.; Yue, Y. J.; Nelson, C.; Blattner, F.; Sussman, M. R.; Cerrina, F. Nat. Biotechnol. 1999, 17, 974.

(5) Li, S. W.; Bowerman, D.; Marthandan, N.; Klyza, S.; Luebke, K. J.; Garner, H. R.; Kodadek, T. J. Am. Chem. Soc. 2004, 126, 4088.

(6) (a) Vossmeyer, T.; DeIonno, E.; Heath, J. R. Angew. Chem., Int. Ed. 1997, 36, 1080. (b) Vossmeyer, T.; Jia, S.; DeIonno, E.; Diehl, M. R.; Kim, S. H.; Peng, X.; Alivisatos, A. P.; Heath, J. R. J. Appl. Phys. 1998, 84, 3664.

(7) Jonas, U.; del Campo, A.; Kruger, C.; Glasser, G.; Boos, D. Proc. Natl. Acad. Sci. U.S.A. 2002, 99, 5034.
(8) Millaruelo, M.; Eng, L. M.; Merting, M.; Pilch, B.; Oertel, U.; Opitz, J.; Sieczkowska, B.; Simon, F.; Voit, B. Langmuir 2006, 22, 9446.

(9) (a) Sundberg, S. A.; Barrett, R. W.; Pirrung, M.; Lu, A. L.; Kiangsoontra, B.; Holmes, C. P. J. Am. Chem. Soc. 1995, 117, 12050. (b) Lee, K. N.; Shin, D. S.; Lee, Y. S.; Kim, Y. K. J. Micromech. Microeng. 2003, 13, 18.

(10) (a) Bhagawati, M.; Lata, S.; Tampe, R.; Piehler, J. J. Am. Chem. Soc. 2010, 132, 5932. (b) Grunwald, C.; Schulze, K.; Reichel, A.; Weiss, V. U.; Blaas, D.; Piehler, J.; Wiesmuller, K. H.; Tampe, R. Proc. Natl. Acad. Sci. U.S.A. 2010, 107, 6146.

(11) (a) Morra, M. J. Biomater. Sci., Polym. Ed. 2000, 11, 547. (b) Dillmore, W. S.; Yousaf, M. N.; Mrksich, M. Langmuir 2004, 20, 7223. (c) Ryan, D.; Parviz, B. A.; Linder, V.; Semetey, V.; Sia, S. K.; Su, J.; Mrksich, M.; Whitesides, G. M. Langmuir 2004, 20, 9080. (d) Hower, J. C.; He, Y.; Bernards, M. T.; Jiang, S. Y. J. Chem. Phys. 2006, 125, 214704.

(12) San Miguel, V.; Bochet, C. G.; del Campo, A. J. Am. Chem. Soc. 2011, 133, 5380 .

(13) Zayat, L.; Salierno, M.; Etchenique, R. Inorg. Chem. 2006, 45, 1728.

(14) Salierno, M.; Marceca, E.; Peterka, D. S.; Yuste, R.; Etchenique, R. J. Inorg. Biochem. 2010, 104, 418.

(15) Bramblett, A. L.; Boeckl, M. S.; Hauch, K. D.; Ratner, B. D.; Sasaki, T.; Rogers, J. W. Surf. Interface Anal. 2002, 33, 506.

(16) Woll, D.; Walbert, S.; Stengele, K. P.; Albert, T. J.; Richmond, T.; Norton, J.; Singer, M.; Green, R. D.; Pfleiderer, W.; Steiner, U. E. Helv. Chim. Acta 2004, 87, 28.

(17) Sullivan, B. P.; Salmon, D. J.; Meyer, T. J. Inorg. Chem. 1978, 17, 3334.

(18) Durham, B.; Caspar, J. V.; Nagle, J. K.; Meyer, T. J. J. Am. Chem. Soc. 1982, 104, 4803

(19) Pinnick, D. V.; Durham, B. Inorg. Chem. 1984, 23, 1440.

(20) Nikolenko, V.; Yuste, R.; Zayat, L.; Baraldo, L. M.; Etchenique, R. Chem. Commun. 2005, 1752.

(21) Alvarez, M.; Best, A.; Pradhan-Kadam, S.; Koynov, K.; Jonas, U.; Kreiter, M. Adv. Mater. 2008, 20, 4563.

(22) Göppert-Mayer, M. Ann. Phys. 1931, 9, 273. 